\title{
Theoretical studies on carbonyl halide-water complexes
}

\author{
Nobuaki Tanaka ${ }^{\text {a,* }}$, Takumi Tamezane ${ }^{\text {a }}$, Hiromasa Nishikiori ${ }^{\text {a }}$, Tsuneo Fujii ${ }^{\text {a }}$, Wade N. \\ Sisk $^{\mathbf{b}}$ \\ a Department of Environmental Science and Technology, Faculty of Engineering, Shinshu \\ University, 4-17-1 Wakasato, Nagano, Nagano 380-8553, Japan \\ ${ }^{\mathrm{b}}$ Chemistry Department, University of North Carolina at Charlotte \\ 9201 University City Blvd., Charlotte, NC 28223-0001, USA \\ Received
}

\begin{abstract}
Theoretical investigations of carbonyl halide complexes, $\mathrm{FXCO}-\mathrm{H}_{2} \mathrm{O}(\mathrm{X}=\mathrm{F}, \mathrm{Cl})$ have been performed. Structures and vibrational frequencies are determined at the MP2 and B3LYP levels of theory with basis sets up to aug-cc-pVTZ. Two conformers of FXCO- $\mathrm{H}_{2} \mathrm{O}$ complex have been found. The structures of FXCO- $\mathrm{H}_{2} \mathrm{O}$ complexes are calculated to be (I) coplanar hydrogen-bonded and (II) angular with $\mathrm{C} \cdots \mathrm{O}$ and $\mathrm{O} \cdots \mathrm{H}$ contacts. Complexation causes the $\mathrm{C}=\mathrm{O}$ bond elongation and the $\mathrm{C}-\mathrm{F}$ bond contraction. NBO analysis revealed intermolecular charge transfers occur followed by intramolecular charge rearrangement.
\end{abstract}

Key words: Ab initio, carbonyl halide, NBO, complex, water

* Corresponding author. Fax: +81-26-269-5550.

E-mail address: ntanaka@gipwc.shinshu-u.ac.jp (N. Tanaka). 


\section{Introduction}

To protect the stratosphere from the ozone depletion catalyzed by a chlorine atom, chlorofluorocarbons CFCs have been replaced by substituents, hydrofluorocarbons HFCs [1]. Recently, hydrofluoroethers HFEs are also under consideration for use. These measures have resulted in deceleration of ozone layer destruction due to the chlorine atom released from the photolysis of CFCs. However, HFCs have potential as a green house molecule [2,3]. Of the oxidation products CFCs, HFCs and HFEs, calbonyl difluoride or carbonyl chloride fluoride is observed as a common product [4-8]. Therefore, the properties and the role of carbonyl halides in atmosphere should be known. The stratospheric abundance has been measured for $\mathrm{F}_{2} \mathrm{CO}$, a fluorine atom reservoir [9]. The threshold energies of the first electronic transition $\mathrm{A} \leftarrow \mathrm{X}$ of carbonyl halides were observed to be $4.86,4.79$ and $4.1 \mathrm{eV}$ for $\mathrm{F}_{2} \mathrm{CO}$ [10], $\mathrm{FClCO}$ [11] and $\mathrm{Cl}_{2} \mathrm{CO}$ [12], respectively. In the stratosphere, photodissociation will be the key decomposition process of the molecules. Photolysis quantum yields at $193 \mathrm{~nm}$ were measured to be 0.94, 0.98 and 1.0 for $\mathrm{F}_{2} \mathrm{CO}, \mathrm{FClCO}$ and $\mathrm{Cl}_{2} \mathrm{CO}$, respectively [13-15]. Maul et al. reported the three body decay dynamics of $\mathrm{FClCO}[16]$ and $\mathrm{Cl}_{2} \mathrm{CO}$ [17]. As the photon energy increases, the three-body decay becomes dominant over the two-body decay. In the lower humid atmosphere, the interaction with water should be important. A theoretical study on the $\mathrm{F}_{2} \mathrm{CO}$ reaction with water reveals the primary concerted reaction to form fluoroformic acid and HF [18]. A recent study on the phosgene-water complex shows the complex has two minima on the potential energy surface at the MP2/aug-cc-pVTZ level of theory [19]. The most stable conformer is found to be the T-shape complex where the water oxygen interacts with the phosgene $\mathrm{C}=\mathrm{O}$ bond. 
Weakly bound hydrogen bonded complexes have attracted many researchers [20-23]. Water is a good probe to explore the potential surface and it is widely known that complexation with the water molecule causes the changes in the vibrational frequency and the IR intensity. Complexes possessing large interaction energy may enhance the green house effect [24]. More weakly bound van der Waals complexes of $\mathrm{F}_{2} \mathrm{CO}$ with $\mathrm{Ar}$ [25,26], $\mathrm{N}_{2}$ [26], $\mathrm{Cl}_{2}$ [27] and IF [28] have been investigated by infrared matrix isolation and $\mathrm{ab}$ initio studies. Conformations of the $\mathrm{F}_{2} \mathrm{CO}$ complexes are classified into the T-shape and the coplanar structures. The $\mathrm{F}_{2} \mathrm{CO}-\mathrm{Ar}$ and $\mathrm{F}_{2} \mathrm{CO}-\mathrm{N}_{2}$ complexes have T-shape structures while the $\mathrm{F}_{2} \mathrm{CO}-\mathrm{Cl}_{2}$ and $\mathrm{F}_{2} \mathrm{CO}-\mathrm{IF}$ complexes have planar structures. In $\mathrm{F}_{2} \mathrm{CO}-\mathrm{N}_{2}$, the $\mathrm{N}_{2}$ molecular axis is perpendicular to the $\mathrm{F}_{2} \mathrm{CO}$ molecular plane.

In this paper, we discuss the structure and energetics of the carbonyl halide-water complexes, $\mathrm{FXCO}-\mathrm{H}_{2} \mathrm{O}(\mathrm{X}=\mathrm{F}, \mathrm{Cl})$, obtained by the MP2 and B3LYP calculations. Comparison with the corresponding $\mathrm{Cl}_{2} \mathrm{CO}-\mathrm{H}_{2} \mathrm{O}$ complex will be made.

\section{Method of calculation}

Geometry optimizations are performed at the second-order Møller-Plesset theory, MP2 using PC GAMESS version [29] of the GAMESS (US) QC package [30] and GAUSSIAN 03W [31]. For weak bonding, both diffuse and polarization functions must be included in the basis set, so we used the $6-311++\mathrm{G}(2 \mathrm{~d}, 2 \mathrm{p})$ and Dunning's correlation consistent triple zeta basis set augmented with diffuse functions, aug-cc-pVTZ) [32,33] obtained from the Extensible Computational Chemistry Environment Basis Set Database, Version 7/30/02 [34]. After structural optimization, single-points calculations are 
performed with the coupled-cluster theory, $\operatorname{CCSD}(\mathrm{T}) / 6-311++\mathrm{G}(2 \mathrm{~d}, 2 \mathrm{p})$ level and the MP2 level using the basis sets up to aug-cc-pV5Z. Analysis of the charge distribution and charge-transfer processes was performed using the natural bond orbital (NBO) partitioning scheme [35] with the aug-cc-pVTZ basis set. For comparison the DFT calculations were employed using the GAUSSIAN 03W program. The basis set superposition error (BSSE) was calculated according to the counterpoise (CP) method proposed by Boys and Bernardi [36].

\section{Results and discussion}

\subsection{Geometry and interaction energy of complex}

Structural parameters of $\mathrm{F}_{2} \mathrm{CO}$ and $\mathrm{FClCO}$ are given in Table 1. The calculated structural parameters of $\mathrm{F}_{2} \mathrm{CO}$ and $\mathrm{FClCO}$ are in good agreement with experimental values [37,38]. Firstly geometry optimizations of the complex were performed at the MP2/6-311++G(d,p) level starting from different initial positions of the two monomers, which converged to two minima. Based on the structures, further optimization at higher level and DFT optimization were employed. Two stable conformations calculated with the MP2/aug-cc-pVTZ level are shown in Figure 1 and geometric parameters are listed in Tables 2 and 3 for the $\mathrm{F}_{2} \mathrm{CO}-\mathrm{H}_{2} \mathrm{O}$ and $\mathrm{FClCO}-\mathrm{H}_{2} \mathrm{O}$ complexes, respectively. $\quad$ It is seen that the bond lengths and angles for the complexes are slightly perturbed from their values in the monomers. In complex $\mathrm{I}, \mathrm{FXCO}$ and $\mathrm{H}_{2} \mathrm{O}$ form a coplanar hydrogen bonding. For FClCO, $\mathrm{H}_{2} \mathrm{O}$ locates on the $\mathrm{F}$ side of the molecule. The calculated distances for 
$\mathrm{O} 2 \cdots \mathrm{H} 6$ and $\mathrm{O} 2 \cdots \mathrm{O} 5$ are 2.086 and $3.033 \AA$, respectively, for $\mathrm{F}_{2} \mathrm{CO}-\mathrm{H}_{2} \mathrm{O}$ and 2.087 and $3.044 \AA$, respectively, for $\mathrm{FClCO}-\mathrm{H}_{2} \mathrm{O}$, which are the properties for the moderate hydrogen bond [22]. The $\mathrm{C} 1-\mathrm{O} 2$ and $\mathrm{O} 5-\mathrm{H} 6$ bonds are elongated by 0.0036 and $0.0025 \AA$, respectively upon formation of the hydrogen bond, while the C1-F3 and C1-F4 bonds are contracted by 0.0065 and $0.0046 \AA$, respectively for the $\mathrm{F}_{2} \mathrm{CO}-\mathrm{H}_{2} \mathrm{O}$ complex. The contraction is larger for the $\mathrm{C}-\mathrm{F}$ bond close to the $\mathrm{H}_{2} \mathrm{O}$ molecule. The angles are slightly sensitive to the complexation. Similar changes are predicted for the $\mathrm{FClCO}-\mathrm{H}_{2} \mathrm{O}$ complex. In complex II of FXCO- $\mathrm{H}_{2} \mathrm{O}$, the molecular plane of $\mathrm{H}_{2} \mathrm{O}$ tilts toward the $\mathrm{F}$ atom in contrast to the most stable $\mathrm{Cl}_{2} \mathrm{CO}-\mathrm{H}_{2} \mathrm{O}$ complex where $\mathrm{H}_{2} \mathrm{O}$ molecular plane is almost perpendicular to that of $\mathrm{Cl}_{2} \mathrm{CO}$ [19]. The distances for $\mathrm{C} 1 \cdots \mathrm{O} 5, \mathrm{O} 2 \cdots \mathrm{O} 5$ and $\mathrm{O} 2 \cdots \mathrm{H} 6$ are calculated to be $2.644,2.950$ and $2.905 \AA$, respectively, for the $\mathrm{F}_{2} \mathrm{CO}-\mathrm{H}_{2} \mathrm{O}$ complex and 2.758, 2.937 and $2.752 \AA$, respectively, for the $\mathrm{FClCO}-\mathrm{H}_{2} \mathrm{O}$ complex. The contractions of the C-F and C-Cl bonds are smaller compared with those of the complex I. Both O5-H6 and O5-H7 bonds are lengthened at the MP2 level, while the O5-H6 bond is lengthened and the O5-H7 bond is contracted at the B3LYP level. Compared with the MP2 calculation, the intermolecular distances optimized at the B3LYP level are longer for both complexes. There is a small difference in the equilibrium structures of the complexes obtained by the MP2 and B3LYP calculations.

(Fig. 1 and Tables 1-3)

Calculated interaction energies including BSSE correction for the complexes are listed in Table 4. As shown complex II is more stable than complex I irrespective of the calculation levels. With the aug-cc-pVTZ basis set, DFT calculation underestimates the energies compared with the MP2 calculation presumably due to the lack of contribution of dispersion interactions [39]. The influence of higher correlation effects on the energies 
was investigated by the single point calculation for the MP2 geometry. With the $6-311++\mathrm{G}(2 \mathrm{~d}, 2 \mathrm{p})$ basis set, the energies obtained at the MP2, MP4SDTQ and CCSD(T) levels are comparable. The CBS limit energies at the MP2 level are obtained using the equation $E(\mathrm{X})=E_{\mathrm{CBS}}+A \exp (-(\mathrm{X}-1))+B \exp \left(-(\mathrm{X}-1)^{2}\right)[40]$ with the correlation-consistent basis sets, aug-cc-pVXZ (X = T, Q and 5). Convergence is faster for the complex I. The calculation for the complex II requires large basis sets to evaluate the dispersion interaction. At the MP2 level, the interaction energies are calculated to be $-4.17,-3.52$ and $-3.18 \mathrm{kcal} \mathrm{mol}^{-1}$ for the angular $\mathrm{F}_{2} \mathrm{CO}, \mathrm{FClCO}$ and $\mathrm{Cl}_{2} \mathrm{CO}$ complexes, respectively. The HF/aug-cc-pV5Z energy for $\mathrm{Cl}_{2} \mathrm{CO}-\mathrm{H}_{2} \mathrm{O}$ was calculated to be $-1.10 \mathrm{kcal} \mathrm{mol}^{-1}$. The complex correlation energy increases in the order $\mathrm{F}_{2} \mathrm{CO}-\mathrm{H}_{2} \mathrm{O}, \mathrm{FClCO}-\mathrm{H}_{2} \mathrm{O}$ and $\mathrm{Cl}_{2} \mathrm{CO}-\mathrm{H}_{2} \mathrm{O}$, indicative of the larger contribution of the dispersion energy for chlorine compounds. This trend is also supported by the fact that the polarizabilities of $\mathrm{F}_{2} \mathrm{CO}, \mathrm{FClCO}$ and $\mathrm{Cl}_{2} \mathrm{CO}$ are calculated to be 14.0, 23.4 and 31.9 au, respectively, at the MP2/aug-cc-pVTZ level.

(Table 4)

\subsection{Vibrational frequencies and intensities}

To elucidate the influence of the complexation on the vibrational spectra of the monomers forming complexes, the accuracy of the calculations are compared in Table 5 for the vibrational frequencies and infrared intensities of the monomers at the MP2 and B3LYP levels of theory with the aug-cc-pVTZ basis set. The calculated values of the vibrational frequencies at the MP2 level are in better agreement with the experimental values [41,42] than those obtained at the B3LYP level. The calculated values for the O-H stretching vibrations of the water deviate significantly from experimental values. The calculated 
frequencies give reasonable predictions for the complex vibrations possessing small anharmonicities. Tables 6 and 7 show unscaled vibrational frequencies and infrared intensities of the complexes I and II calculated using the aug-cc-pVTZ basis set, respectively. In our previous studies it was shown that the complexation leads to the substantial changes in the vibrational characteristics for the vibrations of the monomer bonds not only participating in the complexation but also spectators [19]. As a result of geometry change after complexation, the asymmetric and symmetric O-H stretching and C1-O2 stretching vibrational frequencies decrease, while the other vibrational frequencies increase for complex I. Among the latter vibrations the $\mathrm{CF}_{2}$ symmetric stretching and C-F stretching vibrations are most sensitive to the complexation for the $\mathrm{F}_{2} \mathrm{CO}-\mathrm{H}_{2} \mathrm{O}$ and FClCO- $\mathrm{H}_{2} \mathrm{O}$ complexes, respectively.

The basic trend of the shifts is the same as that of the hydrogen-bonded $\mathrm{H}_{2} \mathrm{CO}-\mathrm{H}_{2} \mathrm{O}$ complex [43]. For complex II, both asymmetric and symmetric O-H stretching vibrational frequencies are shifted to lower frequencies, corresponding to the O5-H6 and O5-H7 bond elongation. Out-of-plane deformation vibrations are shifted to lower frequencies. Similar to complex I, the $\mathrm{C}-\mathrm{F}$ and $\mathrm{C}-\mathrm{Cl}$ stretching frequencies are blue-shifted upon the complexation and the intensities of these bands decrease.

In addition to the intramolecular vibrations, there are six more intermolecular vibrations, the stretching vibration, three torsional vibrations and two in-plane bending vibrations.

(Tables 5-7)

\subsection{Charge distribution}


To clarify the nature of the complexation, the NBO analysis was carried out. Table 8 gives the natural atomic charges $(q)$ for monomers and the changes in natural atomic charges $(\Delta q)$ for complexes calculated with the aug-cc-pVTZ basis set. The negativity of oxygen atoms $\mathrm{O} 2$ and $\mathrm{O} 5$ increases in complexes in comparison with those of the monomer. In complex I, the positivity of the $\mathrm{C} 1$ and $\mathrm{H} 6$ atoms greatly increase. The in-contact bonds become more polarized. On the other hand, in complex II the hydrogen atoms lose charges while the fluorine atoms gain charge. The net charge transfer (CT) was evaluated to be 3.6 (3.8) me for $\mathrm{F}_{2} \mathrm{CO}(\mathrm{FClCO})$ to $\mathrm{H}_{2} \mathrm{O}$ for complex I and 3.9 (3.9) me for $\mathrm{H}_{2} \mathrm{O}$ to $\mathrm{F}_{2} \mathrm{CO}(\mathrm{FClCO})$ for complex II.

(Table 8)

Tables 9 and 10 list the second-order perturbation energies and the changes in electron density in the orbitals for complexes I and II, respectively. The second-order perturbation analysis of the Fock matrix indicated the important intermolecular interactions (1) $n_{1 \mathrm{O} 2} \rightarrow \sigma^{*} \mathrm{O} 5-\mathrm{H} 6$ and (2) $n_{2} \mathrm{O} 2 \rightarrow \sigma_{\mathrm{O} 5-\mathrm{H} 6}^{*}$ for complex I and (1) $n_{2} \mathrm{O} 5 \rightarrow \pi^{*} \mathrm{C} 1-\mathrm{O} 2$ for complex II. For complex I, the primary effect is the charge transfer from carbonyl oxygen lone pair, $n_{2} \mathrm{O} 2$, of FXCO to the O5-H6 antibonding orbital, $\sigma^{*}{ }_{\mathrm{O} 5-\mathrm{H} 6}$ of water. An increase in the electron density in $\sigma_{\mathrm{O}-\mathrm{H} 6}^{*}$ orbital leads to weakening of the $\mathrm{O} 5-\mathrm{H} 6$ bond accompanied by its elongation. Concomitant structural reorganization of the electron donor takes place. The $\pi^{*}{ }_{\mathrm{C} 1-\mathrm{O} 2}$ orbital gains population due to the increase of the $n_{3} \mathrm{~F} 3 \rightarrow$ $\pi^{*} \mathrm{C} 1-\mathrm{O} 2$ and $n_{3 \mathrm{X} 4} \rightarrow \pi^{*} \mathrm{C} 1-\mathrm{O} 2$ interactions. The $\sigma^{*} \mathrm{C} 1-\mathrm{F} 3$ and $\sigma^{*} \mathrm{C} 1-\mathrm{X} 4$ orbitals lose population mainly due to the decrease of $n_{2} \mathrm{O} 2 \rightarrow \sigma_{\mathrm{C} 1-\mathrm{F} 3}$ and $n_{2} \mathrm{O} 2 \rightarrow \sigma_{\mathrm{C} 1-\mathrm{X} 4}$ interactions. The population increases in the $\sigma^{*} \mathrm{C1-O}, \pi^{*} \mathrm{C1-O2}$, and $n_{2} \mathrm{O} 2$ orbitals cause the elongation of the $\mathrm{C} 1-\mathrm{O} 2$ bond and the red shifts of the $\mathrm{C} 1-\mathrm{O} 2$ stretching vibrational frequency, while the 
population decreases in the $\sigma_{\mathrm{C} 1-\mathrm{F} 3}^{*}, \sigma_{\mathrm{C} 1-\mathrm{X} 4}^{*}, n_{3 \mathrm{~F} 3}$, and $n_{3 \mathrm{X} 4}$ orbitals lead to contractions of the $\mathrm{C} 1-\mathrm{F} 3$ and $\mathrm{C} 1-\mathrm{X} 4$ bonds and the blue shifts of the C-F and C-X stretching vibrational frequencies. The CT interactions in complex II is similar to the T-shape $\mathrm{Cl}_{2} \mathrm{CO}-\mathrm{H}_{2} \mathrm{O}$ complex. For complex II, the charge transfer from the water lone pair, $n_{2} 0_{5}$, to the C1-O2 antibonding orbital, $\pi^{*}{ }_{\mathrm{Cl}-\mathrm{O} 2}$, of $\mathrm{HXCO}$ is noticeable. It leads to the $\mathrm{C} 1-\mathrm{O} 2$ bond weakening and elongation. Compared with the complex I, the intramolecular charge rearrangement is smaller for the complex II, which causes smaller structural changes from the monomer after the complexation.

(Tables 9 and 10)

\subsection{Comparison of potential energy surfaces of carbonyl halides}

Since the angular conformer is found to be the most stable complex, we concentrate on this conformation and compare the potential energy surfaces of three carbonyl halides. Fig. 2 shows the potential energy changes at the $\operatorname{CCSD}(\mathrm{T}) / 6-311++\mathrm{G}(2 \mathrm{~d}, 2 \mathrm{p})$ level as a function of the dihedral angle $\varphi_{\mathrm{C} 1 \mathrm{O} 5 \mathrm{H} 6 \mathrm{H} 7}$ including the result for the $\mathrm{Cl}_{2} \mathrm{CO}-\mathrm{H}_{2} \mathrm{O}$ complex for comparison. The $\mathrm{H}_{2} \mathrm{O}$ complex with $\mathrm{F}_{2} \mathrm{CO}$ has the double-well potential, while there is no stationary point for the $\mathrm{Cl}$ side of the FClCO- $\mathrm{H}_{2} \mathrm{O}$ complex. This will be attributed to the difference in the C-F and $\mathrm{C}-\mathrm{Cl}$ bond lengths. However, the barrier height to flipping for the former complex is very small.

(Fig. 2)

Fig. 3 shows the potential energy changes at the MP2/6-311++G(2d,2p) level as a function of the intermolecular distance $r_{\mathrm{C} 105}$. For the $\mathrm{FClCO}-\mathrm{H}_{2} \mathrm{O}$ complex, the conformation

change occurred at the distance longer than $5.0 \AA$ from perpendicular to planar with a 


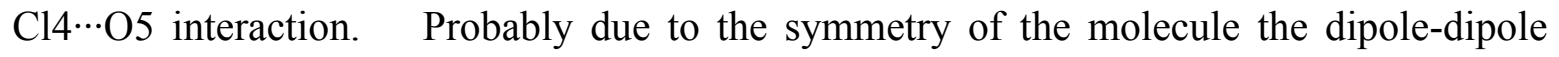
interaction favors the planar conformation at the longer distance.

(Fig. 3)

Fig. 4 illustrates the comparison of the electrostatic potentials of three carbonyl halides at 0.015 a.u. where the light and dark gray surfaces represent the positive and negative potentials, respectively. Since the electrostatic potential is the energy of a positive test charge at a given location, the oxygen and hydrogen atoms of the water molecule should favor the positive and negative regions of the potential, respectively. The negative potentials spread around the $\mathrm{O} 2$ atom where a preferable hydrogen bond will be made. The positive potential for $\mathrm{F}_{2} \mathrm{CO}$ deviates along the axis perpendicular to the molecular plane, while for $\mathrm{FClCO}$ and $\mathrm{Cl}_{2} \mathrm{CO}$ it deviates along the $\mathrm{C}-\mathrm{Cl}$ bond. It is reasonable that the $\mathrm{C} \cdots \mathrm{O}$ approaches of water along the axis perpendicular to the carbonyl halide molecular plane give the most stable T-shape complexes with $\mathrm{C} 1 \cdots \mathrm{O} 5$ and $\mathrm{O} 2 \cdots \mathrm{H} 6$ interactions. For $\mathrm{Cl}_{2} \mathrm{CO}$, the $\mathrm{Cl}$ atom possesses another possible point to form the $\mathrm{Cl} \cdots \mathrm{O}$ complex.

(Fig. 4)

\section{Conclusions}

Theoretical studies on the carbonyl halide-water complexes, FXCO- $\mathrm{H}_{2} \mathrm{O}(\mathrm{X}=\mathrm{F}$, $\mathrm{Cl}$ ) have found two potential minima at the MP2 and B3LYP level. Complex I forms $\mathrm{C}=\mathrm{O} \cdots \mathrm{H}$ hydrogen bond with the planar conformation where stretching vibrations involved in hydrogen bonding are shifted to lower frequencies with enhancement of infrared intensities, corresponding to the bond elongation. The more stable complex II has the 
non-hydrogen bonded angular conformation. Structural changes from monomers are small compared with complex I. The B3LYP calculation underestimates the complexation energies and predicts longer intermolecular distances compared with the MP2 calculation. NBO analysis revealed intermolecular charge transfer occur followed by intramolecular charge rearrangement. Significant charge transfer from the carbonyl oxygen lone pairs to water $\sigma_{\mathrm{O}-\mathrm{H}}^{*}$ for complex I and from one of the water oxygen lone pairs to the $\pi^{*}{ }_{\mathrm{C}=\mathrm{O}}$ for complex II takes place. The overall charge transfer was from $\mathrm{F}_{2} \mathrm{CO}$ to $\mathrm{H}_{2} \mathrm{O}$ for complex I and from $\mathrm{H}_{2} \mathrm{O}$ to $\mathrm{F}_{2} \mathrm{CO}$ for complex II.

This work was partly supported by the Grant-in-Aid for Encouragement of Young Scientists (No. 14750574) from the Ministry of Education, Culture, Sports, Science, and Technology of Japan.

\section{References}

[1] A. McCulloch, J. Fluor. Chem. 100 (1999) 163.

[2] A. McCulloch, J. Fluor. Chem. 123 (2003) 21.

[3] S.J. Tavener, J.H. Clark, J. Fluor. Chem. 123 (2003) 31.

[4] F. Wu, R.W. Carr, J. Phys. Chem. 96 (1992) 1743.

[5] X. Cheng, Y. Zhao, Z. Zhou, J. Mol. Struct. (Theochem) 673 (2004) 43.

[6] R.V. Olkhov, I.W.M. Smith, Phys. Chem. Chem. Phys. 5 (2003) 3436.

[7] F. Cavalli, M. Glasius, J. Hjorth, B. Rindone, N.R. Jensen, Atomos. Environ. 32 (1998) 3767.

[8] Y. Inoue, M. Kawasaki, T.J. Wallington, M.D. Hurley, Chem. Phys. Lett. 343 (2001) 296. 
[9] R. Zander, C.P. Rinsland, E. Mahieu, M.R. Gunson, C.B. Farmer, M.C. Abrams, M.K.W. Ko, J. Geophys. Res. 99 (1994) 16737.

[10] R.H. Judge, D.C. Moule, J. Chem. Phys. 78 (1983) 4806.

[11] I. Zanon, G. Giacometti, D. Picciol, Spectochim. Acta 19 (1963) 301.

[12] S.R. LaPaglia, A.B.F. Duncan, J. Chem. Phys. 34 (1961) 125.

[13] A. Nölle, C. Krumscheid, H. Heydtmann, Chem. Phys. Lett. 299 (1999) 561.

[14] M. Hermann, A. Nölle, H. Heydtmann, Chem. Phys. Lett. 226 (1994) 559.

[15] M. Jäger, H. Heydtmann, C. Zetzsch, Chem. Phys. Lett. 263 (1996) 817.

[16] C. Maul, K.-H. Gericke, J. Phys. Chem. A 104 (2000) 2531.

[17] C. Maul, T. Hass, K.-H. Gericke, J. Phys. Chem. A 101 (1997) 6619.

[18] M.R. Zachariah, W. Tsang, P.R. Westmoreland, D.R.F. Burgess, Jr., J. Phys. Chem. 99 (1995) 12512.

[19] N. Tanaka, T. Tamezane, H. Nishikiori, T. Fujii, J. Mol. Struct. (Theochem) 21 (2003) 631.

[20] G.C. Pimentel, A.L. McClellan, The Hydrogen Bond, Freeman, San Francisco, 1960.

[21] G.R. Desiraju, T. Steiner, The Weak Hydrogen Bond, Oxford University Press, Oxford, 1999.

[22] G.A. Jeffrey, An Introduction to Hydrogen Bonding, Oxford University Press, New York, 1997.

[23] S. Scheiner, Hydrogen Bonding, Oxford University Press, New York, 1997.

[24] I.M. Svishchev, R.J. Boyd, J. Phys. Chem. A 102 (1998) 7294.

[25] J.A. Shea, E.J. Campbell, J. Chem. Phys. 79 (1983) 4724.

[26] A.A. Stolov, W.A. Herrebout, B.J. Van der Veken, J. Phys. Chem. A 103 (1999) 5291. 
[27] Y. Bouteiller, O. Abdelaoui, A. Schriver, L. Schriver-Mazzuoli, J. Chem. Phys. 102 (1995) 1731.

[28] L. Andrews, M. Hawkins, R. Withnall, Inorg. Chem. 24 (1985) 4234.

[29] A.A. Granovsky, www http://classic.chem.msu.su/gran/gamess/index.html.

[30] M.W. Schmidt, K.K. Baldridge, J.A. Boatz, S.T. Elbert, M.S. Gordon, J.J. Jensen, S.

Koseki, N. Matsunaga, K.A. Nguyen, S. Su, T.L. Windus, M. Dupuis, J.A. Montgomery, J. Comput. Chem. 14 (1993) 1347.

[31] M.J. Frisch, G.W. Trucks, H.B. Schlegel, G.E. Scuseria, M.A. Robb, J.R. Cheeseman, J.A. Montgomery, Jr., T. Vreven, K.N. Kudin, J.C. Burant, J.M. Millam, S.S. Iyengar, J. Tomasi, V. Barone, B. Mennucci, M. Cossi, G. Scalmani, N. Rega, G.A. Petersson, H. Nakatsuji, M. Hada, M. Ehara, K. Toyota, R. Fukuda, J. Hasegawa, M. Ishida, T. Nakajima, Y. Honda, O. Kitao, H. Nakai, M. Klene, X. Li, J.E. Knox, H.P. Hratchian, J.B. Cross, C. Adamo, J. Jaramillo, R. Gomperts, R.E. Stratmann, O. Yazyev, A.J. Austin, R. Cammi, C. Pomelli, J.W. Ochterski, P.Y. Ayala, K. Morokuma, G.A. Voth, P. Salvador, J.J. Dannenberg, V.G. Zakrzewski, S. Dapprich, A.D. Daniels, M.C. Strain, O. Farkas, D.K. Malick, A.D. Rabuck, K. Raghavachari, J.B. Foresman, J.V. Ortiz, Q. Cui, A.G. Baboul, S. Clifford, J. Cioslowski, B.B. Stefanov, G. Liu, A. Liashenko, P. Piskorz, I. Komaromi, R.L. Martin, D.J. Fox, T. Keith, M.A. Al-Laham, C.Y. Peng, A. Nanayakkara, M. Challacombe, P.M.W. Gill, B. Johnson, W. Chen, M.W. Wong, C. Gonzalez, J.A. Pople, Gaussian 03, Revision B.03, Gaussian, Inc., Pittsburgh PA, 2003.

[32] R.A. Kendall, T.H. Dunning, Jr., R.J. Harrison, J. Chem. Phys. 96 (1992) 6796.

[33] D.E. Woon, T.H. Dunning, Jr., J. Chem. Phys. 98 (1993) 1358.

[34] Molecular Science Computing Facility, Environmental and Molecular Sciences Laboratory which is part of the Pacific Northwest Laboratory, P.O. Box 999, Richland, 
Washington 99352, USA, and funded by the U.S. Department of Energy. The Pacific Northwest Laboratory is a multi-program laboratory operated by Battelle Memorial Institue for the U.S. Department of Energy under contract DE-AC06-76RLO 1830. Contact David Feller or Karen Schuchardt for further information.

[35] A.E. Reed, L.A. Curtiss, F. Weinhold, Chem. Rev. 88 (1988) 899.

[36] S.F. Boys, F. Bernardi, Mol. Phys. 19 (1970) 553.

[37] M. Nakata, K. Kohata, T. Fukuyama, K. Kuchitsu, C. J. Wilkins, J. Mol. Struct. 68 (1980) 271.

[38] N. Heineking, W. Jager, M.C.L. Gerry, J. Mol. Spectrosc. 158 (1993) 69.

[39] S. Kristyán, P. Pulay, Chem. Phys. Lett. 229 (1994) 175.

[40] K.A. Peterson, D.E. Woon, T.H. Dunning, Jr., J. Chem. Phys. 100 (1994) 7410.

[41] T. Shimanouchi, Tables of Molecular Vibrational Frequencies Consolidated Volume I, National Bureau of Standards, 1972, 1-160.

[42] A.M. Nielsen, T.G. Burke, P.J.H. Woltz, E.A. Jones, J. Chem. Phys. 20 (1952) 596.

[43] Y. Dimitrova, J. Mol. Struct. (Theochem) 391 (1997) 251. 


\section{Figure captions}

Fig. 1. Optimized geometries of the FXCO- $\mathrm{H}_{2} \mathrm{O}$ (a) complex I and (b) complex II calculated at the MP2/aug-cc-pVTZ level of theory. Intermolecular distances are denoted in A. Upper, $\mathrm{F}_{2} \mathrm{CO}-\mathrm{H}_{2} \mathrm{O}$. Lower, $\mathrm{FClCO}-\mathrm{H}_{2} \mathrm{O}$.

Fig. 2. Potential energies as a function of dihedral angle $\varphi_{\mathrm{C} 105 \mathrm{H} 6 \mathrm{H} 7}$ for the complex II of $\mathrm{F}_{2} \mathrm{CO}(\circ), \mathrm{FClCO}(\square)$ and $\mathrm{Cl}_{2} \mathrm{CO}(\Delta)$ calculated at the $\mathrm{CCSD}(\mathrm{T}) / 6-311++(2 \mathrm{~d}, 2 \mathrm{p})$ level.

Fig. 3. Intermolecular potential energies for the complex II of $\mathrm{F}_{2} \mathrm{CO}(\circ), \mathrm{FClCO}(\square)$ and $\mathrm{Cl}_{2} \mathrm{CO}(\Delta)$ calculated at the MP2/6-311++(2d,2p) level.

Fig. 4. Electrostatic potential surfaces at 0.015 a.u. for (a) $\mathrm{F}_{2} \mathrm{CO}$, (b) $\mathrm{FClCO}$ and (c) $\mathrm{Cl}_{2} \mathrm{CO}$. Upper and lower represent the top and side views of the surface for the molecular plane, respectively. 
Table 1

Geometry parameters of $\mathrm{F}_{2} \mathrm{CO}$ and $\mathrm{FClCO}$

\begin{tabular}{|c|c|c|c|c|}
\hline \multirow{2}{*}{ Parameter $^{\mathrm{a}}$} & \multicolumn{2}{|c|}{ MP2 } & \multirow{2}{*}{$\begin{array}{c}\text { B3LYP } \\
\text { aug-cc-pVTZ }\end{array}$} & \multirow[t]{2}{*}{$\operatorname{Exp}^{b}$} \\
\hline & $6-311++G(2 d, 2 p)$ & aug-cc-pVTZ & & \\
\hline \multicolumn{5}{|l|}{$\mathrm{F}_{2} \mathrm{CO}$} \\
\hline \multicolumn{5}{|l|}{ Bond length } \\
\hline$r_{\mathrm{CF}}$ & 1.321 & 1.316 & 1.319 & 1.3157 \\
\hline$r_{\mathrm{CO}}$ & 1.177 & 1.178 & 1.171 & 1.1717 \\
\hline \multicolumn{5}{|l|}{ Angle } \\
\hline$\theta_{\mathrm{FCO}}$ & 126.2 & 126.2 & 126.2 & 126.15 \\
\hline$\theta_{\mathrm{FCF}}$ & 107.6 & 107.5 & 107.7 & 107.71 \\
\hline \multicolumn{5}{|l|}{ Dihedral angle } \\
\hline$\varphi_{\mathrm{COFF}}$ & 0.0 & 0.0 & 0.0 & 0.0 \\
\hline \multicolumn{5}{|l|}{ FClCO } \\
\hline \multicolumn{5}{|l|}{ Bond length } \\
\hline$r_{\mathrm{CF}}$ & 1.334 & 1.330 & 1.331 & 1.324 \\
\hline$r_{\mathrm{CCl}}$ & 1.737 & 1.724 & 1.743 & 1.733 \\
\hline$r_{\mathrm{CO}}$ & 1.180 & 1.181 & 1.172 & 1.172 \\
\hline \multicolumn{5}{|l|}{ Angle } \\
\hline$\theta_{\mathrm{FCO}}$ & 124.1 & 124.2 & 124.2 & 124.70 \\
\hline$\theta_{\mathrm{ClCO}}$ & 126.5 & 126.6 & 126.5 & 126.1 \\
\hline$\theta_{\mathrm{FCCl}}$ & 109.3 & 109.3 & 109.3 & 109.22 \\
\hline \multicolumn{5}{|l|}{ Dihedral angle } \\
\hline$\varphi_{\mathrm{COFCl}}$ & 0.0 & 0.0 & 0.0 & 0.0 \\
\hline
\end{tabular}

${ }^{a}$ Bond lengths and angles are in $\AA$ and degrees, respectively.

${ }^{\mathrm{b}}$ For $\mathrm{F}_{2} \mathrm{CO}$ from Ref. [37] and FClCO from Ref. [38]. 
Table 2

Geometry parameters of the $\mathrm{F}_{2} \mathrm{CO}-\mathrm{H}_{2} \mathrm{O}$ complexes computed at the MP2 and B3LYP levels of theory ${ }^{\mathrm{a}}$

\begin{tabular}{|c|c|c|c|c|c|c|c|c|c|c|c|c|}
\hline \multirow{2}{*}{$\begin{array}{l}\text { Parameters }^{\mathrm{b}} \\
\text { Bond length }\end{array}$} & \multicolumn{6}{|c|}{ Complex I } & \multicolumn{6}{|c|}{ Complex II } \\
\hline & \multicolumn{2}{|c|}{ MP2/6-311++G(2d2p) } & \multicolumn{2}{|c|}{ MP2/aug-cc-pVTZ } & \multicolumn{2}{|c|}{ B3LYP/aug-cc-pVTZ } & \multicolumn{2}{|c|}{ MP2/6-311++G(2d2p) } & \multicolumn{2}{|c|}{ MP2/aug-cc-pVTZ } & \multicolumn{2}{|c|}{ B3LYP/aug-cc-pVTZ } \\
\hline$r_{\mathrm{C} 1 \mathrm{~F} 3}$ & 1.314 & $(-0.0068)$ & 1.310 & $(-0.0065)$ & 1.313 & $(-0.0063)$ & 1.320 & $(-0.0002)$ & 1.315 & $(-0.0007)$ & 1.319 & $(-0.0003)$ \\
\hline$r_{\mathrm{C} 1 F 4}$ & 1.316 & $(-0.0046)$ & 1.312 & $(-0.0046)$ & 1.315 & $(-0.0044)$ & 1.317 & $(-0.0034)$ & 1.313 & $(-0.0033)$ & 1.316 & $(-0.0030)$ \\
\hline$r_{\mathrm{C} 1 \mathrm{O} 2}$ & 1.181 & $(+0.0037)$ & 1.181 & $(+0.0036)$ & 1.175 & $(+0.0037)$ & 1.178 & $(+0.0013)$ & 1.179 & $(+0.0014)$ & 1.173 & $(+0.0016)$ \\
\hline$r_{\mathrm{O} 5 \mathrm{H} 6}$ & 0.960 & $(+0.0023)$ & 0.964 & $(+0.0025)$ & 0.964 & $(+0.0024)$ & 0.959 & $(+0.0010)$ & 0.962 & $(+0.0009)$ & 0.962 & $(+0.0005)$ \\
\hline$r_{\mathrm{O} 5 \mathrm{H} 7}$ & 0.958 & $(-0.0005)$ & 0.961 & $(-0.0005)$ & 0.961 & $(-0.0007)$ & 0.958 & $(+0.0004)$ & 0.961 & $(+0.0001)$ & 0.962 & $(-0.0001)$ \\
\hline \multicolumn{13}{|l|}{ Angle } \\
\hline$\theta_{\mathrm{F} 3 \mathrm{C} 1 \mathrm{O} 2}$ & 126.1 & $(-0.12)$ & 126.1 & $(-0.09)$ & 126.1 & $(-0.06)$ & 125.9 & $(-0.26)$ & 126.0 & $(-0.25)$ & 125.9 & $(-0.24)$ \\
\hline$\theta_{\mathrm{F} 4 \mathrm{C} 1 \mathrm{O} 2}$ & 125.7 & $(-0.54)$ & 125.7 & $(-0.57)$ & 125.6 & $(-0.53)$ & 126.2 & $(-0.01)$ & 126.2 & $(-0.05)$ & 126.1 & $(-0.03)$ \\
\hline$\theta_{\mathrm{F} 3 \mathrm{C} 1 \mathrm{~F} 4}$ & 108.3 & $(+0.65)$ & 108.2 & $(+0.65)$ & 108.3 & $(+0.72)$ & 107.8 & $(+0.21)$ & 107.8 & $(+0.23)$ & 107.9 & $(+0.22)$ \\
\hline$\theta_{\mathrm{H} 605 \mathrm{H} 7}$ & 104.6 & $(+0.29)$ & 104.4 & $(+0.28)$ & 105.3 & $(+0.22)$ & 104.8 & $(+0.51)$ & 104.7 & $(+0.56)$ & 105.5 & $(+0.43)$ \\
\hline$\theta_{\mathrm{H} 605 \mathrm{O} 2}$ & 9.8 & & 8.9 & & 8.2 & & & & & & & \\
\hline$\theta_{\mathrm{H} 605 \mathrm{C} 1}$ & & & & & & & 103.8 & & 101.3 & & 102.3 & \\
\hline \multicolumn{13}{|l|}{$\begin{array}{l}\text { Dihedral } \\
\text { angle }\end{array}$} \\
\hline$\varphi_{\mathrm{C} 1 \mathrm{O} 2 \mathrm{~F} 3 \mathrm{~F} 4}$ & 0.0 & $(0.00)$ & 0.0 & $(0.00)$ & 0.0 & $(0.00)$ & -1.8 & $(-1.78)$ & -1.9 & $(-1.87)$ & -1.8 & $(-1.79)$ \\
\hline$\varphi_{\mathrm{C} 102 \mathrm{O} 5 \mathrm{H} 6}$ & & & & & & & -172.2 & & -172.8 & & -175.5 & \\
\hline$\varphi_{\mathrm{C} 105 \mathrm{H} 6 \mathrm{H} 7}$ & & & & & & & 139.9 & & 144.3 & & 139.9 & \\
\hline \multicolumn{13}{|l|}{ distance } \\
\hline$r_{\mathrm{C} 1 \mathrm{O} 5}$ & 3.759 & & 3.764 & & 3.878 & & 2.666 & & 2.644 & & 2.773 & \\
\hline
\end{tabular}




\begin{tabular}{ccccccc}
$r_{\mathrm{O} 2 \mathrm{O} 5}$ & 3.052 & 3.033 & 3.089 & 2.991 & 2.950 & 3.080 \\
$r_{\mathrm{O} 2 \mathrm{H} 6}$ & 2.112 & 2.086 & 2.139 & 2.993 & 2.905 & 3.064 \\
\hline${ }^{\mathrm{a}}$ Changes in values from the corresponding monomer are given in parentheses.
\end{tabular}

${ }^{a}$ Changes in values from the corresponding monomer are given in parentheses.

${ }^{\mathrm{b}}$ Bond lengths and angles are in $\AA$ and degrees, respectively. 


\section{Table 3}

Geometry parameters of the FClCO- $\mathrm{H}_{2} \mathrm{O}$ complexes computed at the MP2 and B3LYP levels of theory ${ }^{\mathrm{a}}$

\begin{tabular}{|c|c|c|c|c|c|c|c|c|c|c|c|c|}
\hline \multirow{2}{*}{$\begin{array}{l}\text { Parameters } \\
\text { Bond length }\end{array}$} & \multicolumn{6}{|c|}{ Complex I } & \multicolumn{6}{|c|}{ Complex II } \\
\hline & \multicolumn{2}{|c|}{ MP2/6-311++G(2d2p) } & \multicolumn{2}{|c|}{ MP2/aug-cc-pVTZ } & \multicolumn{2}{|c|}{ B3LYP/aug-cc-pVTZ } & \multicolumn{2}{|c|}{ MP2/6-311++G(2d2p) } & \multicolumn{2}{|c|}{ MP2/aug-cc-pVTZ } & \multicolumn{2}{|c|}{ B3LYP/aug-cc-pVTZ } \\
\hline$r_{\mathrm{C} 1 \mathrm{~F} 3}$ & 1.328 & $(-0.0064)$ & 1.324 & $(-0.0061)$ & 1.325 & $(-0.0056)$ & 1.332 & $(-0.0017)$ & 1.327 & $(-0.0027)$ & 1.329 & $(-0.0020)$ \\
\hline$r_{\mathrm{C} 1 \mathrm{Cl} 4}$ & 1.730 & $(-0.0070)$ & 1.717 & $(-0.0066)$ & 1.736 & $(-0.0067)$ & 1.735 & $(-0.0025)$ & 1.721 & $(-0.0027)$ & 1.741 & $(-0.0022)$ \\
\hline$r_{\mathrm{C} 1 \mathrm{O} 2}$ & 1.184 & $(+0.0040)$ & 1.185 & $(+0.0038)$ & 1.176 & $(+0.0039)$ & 1.181 & $(+0.0011)$ & 1.182 & $(+0.0015)$ & 1.174 & $(+0.0014)$ \\
\hline$r_{\mathrm{O} 5 \mathrm{H} 6}$ & 0.961 & $(+0.0024)$ & 0.964 & $(+0.0026)$ & 0.964 & $(+0.0024)$ & 0.959 & $(+0.0011)$ & 0.963 & $(+0.0012)$ & 0.962 & $(+0.0006)$ \\
\hline$r_{\mathrm{O} 5 \mathrm{H} 7}$ & 0.958 & $(-0.0005)$ & 0.961 & $(-0.0005)$ & 0.961 & $(-0.0006)$ & 0.959 & $(+0.0004)$ & 0.962 & $(+0.0003)$ & 0.962 & $(-0.0001)$ \\
\hline \multicolumn{13}{|l|}{ Angle } \\
\hline$\theta_{\mathrm{F} 3 \mathrm{C} 1 \mathrm{O} 2}$ & 123.9 & $(-0.26)$ & 123.9 & $(-0.24)$ & 124.0 & $(-0.18)$ & 124.0 & $(-0.11)$ & 124.1 & $(-0.10)$ & 124.1 & $(-0.08)$ \\
\hline$\theta_{\mathrm{C} 14 \mathrm{C} 1 \mathrm{O} 2}$ & 126.1 & $(-0.40)$ & 126.2 & $(-0.43)$ & 126.1 & $(-0.39)$ & 126.4 & $(-0.10)$ & 126.4 & $(-0.15)$ & 126.4 & $(-0.12)$ \\
\hline$\theta_{\mathrm{F} 3 \mathrm{C} 1 \mathrm{Cl} 14}$ & 110.0 & $(+0.66)$ & 109.9 & $(+0.64)$ & 109.9 & $(+0.57)$ & 109.5 & $(+0.18)$ & 109.5 & $(+0.21)$ & 109.5 & $(+0.17)$ \\
\hline$\theta_{\mathrm{H} 605 \mathrm{H} 7}$ & 104.4 & $(+0.18)$ & 104.3 & $(+0.23)$ & 105.2 & $(+0.10)$ & 104.7 & $(+0.40)$ & 104.6 & $(+0.50)$ & 105.4 & $(+0.32)$ \\
\hline$\theta_{\mathrm{H} 605 \mathrm{O} 2}$ & 5.4 & & 5.8 & & 4.3 & & & & & & & \\
\hline$\theta_{\mathrm{H} 605 \mathrm{C} 1}$ & & & & & & & 97.8 & & 92.9 & & 92.7 & \\
\hline \multicolumn{13}{|l|}{ Dihedral } \\
\hline \multicolumn{13}{|l|}{ angle } \\
\hline$\varphi_{\mathrm{C} 1 \mathrm{O} 2 \mathrm{~F} 3 \mathrm{Cl} 4}$ & 0.0 & $(0.00)$ & 0.0 & $(0.00)$ & 0.0 & $(0.00)$ & -1.4 & $(-1.43)$ & -1.4 & $(-1.37)$ & -1.3 & $(-1.27)$ \\
\hline$\varphi_{\mathrm{C} 1 \mathrm{O} 2 \mathrm{O} 5 \mathrm{H} 6}$ & & & & & & & -169.1 & & -169.4 & & -170.9 & \\
\hline$\varphi_{\mathrm{C} 105 \mathrm{H} 6 \mathrm{H} 7}$ & & & & & & & 141.0 & & 152.2 & & 140.0 & \\
\hline \multicolumn{13}{|l|}{ Distance } \\
\hline$r_{\mathrm{C} 1 \mathrm{O} 5}$ & 3.861 & & 3.875 & & 3.978 & & 2.773 & & 2.758 & & 2.942 & \\
\hline
\end{tabular}




\begin{tabular}{llllllll}
$r_{\mathrm{O} 205}$ & 3.060 & 3.044 & 3.104 & 3.000 & 2.937 & 3.110 & \\
$r_{\mathrm{O} 2 \mathrm{H} 6}$ & 2.106 & 2.087 & 2.144 & 2.904 & 2.752 & 2.938 \\
\hline
\end{tabular}

${ }^{\text {a }}$ Changes in values from the corresponding monomer are given in parentheses.

${ }^{\mathrm{b}}$ Bond lengths and angles are in $\AA$ and degrees, respectively. 
Table 4

BSSE corrected interaction energies $\left(\mathrm{kcal} \mathrm{mol}^{-1}\right)$ of the $\mathrm{FXCO}-\mathrm{H}_{2} \mathrm{O}$ complexes

\begin{tabular}{ccccc} 
& \multicolumn{3}{c}{$\mathrm{F}_{2} \mathrm{CO}$} & \multicolumn{2}{c}{ FClCO } \\
\cline { 2 - 5 } & complex I & complex II & complex I & complex II \\
HF & & & & \\
6-311++G(2d,2p) & -1.58 & -2.77 & -1.64 & -1.87 \\
aug-cc-pVTZ & -1.65 & -2.78 & -1.71 & -1.81 \\
aug-cc-pVQZ & -1.68 & -2.80 & -1.76 & -1.82 \\
aug-cc-pV5Z & -1.69 & -2.81 & -1.76 & -1.83 \\
MP2 & & & & \\
6-311++G(2d,2p) & -2.18 & -3.32 & -2.13 & -2.73 \\
aug-cc-pVTZ & -2.50 & -3.89 & -2.45 & -3.28 \\
aug-cc-pVQZ & -2.61 & -4.06 & -2.56 & -3.42 \\
aug-cc-pV5Z & -2.64 & -4.13 & -2.58 & -3.48 \\
CBS & -2.66 & -4.17 & -2.59 & -3.52 \\
MP4SDTQ & & & & \\
6-311++G(2d,2p) & -2.21 & -3.30 & -2.18 & -2.67 \\
CCSD(T) & & & & \\
6-311++G(2d,2p) & -2.21 & -3.33 & -2.21 & -2.65 \\
B3LYP & & -2.92 & -2.14 & -1.98 \\
aug-cc-pVTZ & -2.28 & & & \\
\hline
\end{tabular}

${ }^{\text {a }}$ Geometries obtained at the MP2/aug-cc-pVTZ level.

${ }^{\mathrm{b}} E(X)=E_{C B S}+A e^{-(X-1)}+B e^{-(X-1)^{2}}$

${ }^{\mathrm{c}}$ Geometries obtained at the MP2/6-311++G(2d,2p) level. 
Table 5

Unscaled harmonic vibrational frequencies $\left(\mathrm{cm}^{-1}\right)$ and intensities $\left(\mathrm{km} \mathrm{mol}^{-1}\right)$ of monomers calculated at the MP2/aug-cc-pVTZ and B3LYP/aug-cc-pVTZ level of theory ${ }^{\mathrm{a}}$

\begin{tabular}{|c|c|c|c|c|c|c|}
\hline \multirow{2}{*}{ mode } & \multicolumn{2}{|c|}{ MP2 } & \multicolumn{2}{|c|}{ B3LYP } & \multicolumn{2}{|c|}{$\operatorname{Exp}^{a}$} \\
\hline & $v$ & I & $v$ & I & $v$ & I \\
\hline \multicolumn{7}{|l|}{$\mathrm{H}_{2} \mathrm{O}$} \\
\hline $\mathrm{OH}_{2}$ a-str & 3948.2 & 75.0 & 3898.9 & 63.0 & 3755.79 & \\
\hline $\mathrm{OH}_{2}$ s-str & 3818.0 & 6.4 & 3796.2 & 4.6 & 3656.65 & \\
\hline $\mathrm{OH}_{2}$ bend & 1623.2 & 72.0 & 1627.0 & 75.8 & 1594.59 & \\
\hline \multicolumn{7}{|l|}{$\mathrm{F}_{2} \mathrm{CO}$} \\
\hline $\mathrm{C}=\mathrm{O} \operatorname{str}$ & 1949.2 & 431.7 & 1958.2 & 474.6 & 1928 & VS \\
\hline $\mathrm{CF}_{2}$ a-str & 1249.6 & 416.9 & 1218.1 & 423.4 & 1249 & VS \\
\hline $\mathrm{CF}_{2}$ s-str & 972.7 & 65.3 & 963.5 & 60.5 & 965 & VS \\
\hline Oop & 785.1 & 32.2 & 776.2 & 35.0 & 774 & M \\
\hline CO deform & 615.6 & 6.3 & 615.9 & 5.9 & 626 & M \\
\hline $\mathrm{CF}_{2}$ bend & 584.5 & 6.4 & 576.0 & 5.0 & 584 & M \\
\hline \multicolumn{7}{|l|}{$\mathrm{FClCO}$} \\
\hline CO str & 1881.7 & 350.4 & 1908.5 & 410.9 & 1868 & VS \\
\hline CF str & 1097.1 & 415.2 & 1075.6 & 417.1 & 1095 & S \\
\hline $\mathrm{CCl}$ str & 767.3 & 85.0 & 754.1 & 90.6 & 776 & M \\
\hline Oop & 675.4 & 13.0 & 670.6 & 14.8 & 667 & M \\
\hline $\mathrm{CO}$ deform & 508.9 & 0.3 & 489.4 & 1.1 & 501 & $\mathrm{~W}$ \\
\hline $\mathrm{CFCl}$ bend & 413.2 & 0.5 & 405.3 & 0.4 & 415 & VW \\
\hline
\end{tabular}

${ }^{\mathrm{a}}$ For $\mathrm{H}_{2} \mathrm{O}$ from Ref. [41], and for $\mathrm{F}_{2} \mathrm{CO}$ and $\mathrm{FClCO}$ from Ref. [42]. 
Table 6

Unscaled harmonic vibrational frequencies $\left(\mathrm{cm}^{-1}\right)$ and intensities $\left(\mathrm{km} \mathrm{mol}^{-1}\right)$ of the $\mathrm{F}_{2} \mathrm{CO}-\mathrm{H}_{2} \mathrm{O}$ complexes calculated at the MP2/aug-cc-pVTZ level of theory ${ }^{\mathrm{a}}$

\begin{tabular}{|c|c|c|c|c|c|c|c|c|}
\hline \multirow{2}{*}{ mode } & \multicolumn{4}{|c|}{ Complex I } & \multicolumn{4}{|c|}{ Complex II } \\
\hline & $v$ & & I & & $v$ & & I & \\
\hline $\mathrm{OH}$ a-str & 3931.0 & $(-17.2)$ & 178.2 & $(+103.3)$ & 3932.6 & $(-15.6)$ & 84.5 & $(+9.5)$ \\
\hline OH s-str & 3805.7 & $(-12.3)$ & 83.1 & $(+76.6)$ & 3797.1 & $(-20.9)$ & 15.1 & $(+8.7)$ \\
\hline $\mathrm{HOH}$ bend & 1633.0 & $(+9.9)$ & 62.0 & $(-10.0)$ & 1624.5 & $(+1.3)$ & 86.9 & $(+14.9)$ \\
\hline CO str & 1941.1 & $(-8.1)$ & 493.5 & $(+61.8)$ & 1947.3 & $(-2.0)$ & 417.7 & $(-14.0)$ \\
\hline $\mathrm{CF}_{2}$ a-str & 1279.8 & $(+30.2)$ & 400.2 & $(-16.7)$ & 1260.6 & $(+11.0)$ & 393.9 & $(-23.0)$ \\
\hline $\mathrm{CF}_{2} \mathrm{~s}-\mathrm{str}$ & 980.1 & $(+7.5)$ & 57.5 & $(-7.8)$ & 976.3 & $(+3.7)$ & 57.5 & $(-7.7)$ \\
\hline Op deform & 790.3 & $(+5.2)$ & 34.2 & $(+2.0)$ & 770.3 & $(-14.8)$ & 61.5 & $(+29.3)$ \\
\hline $\mathrm{CO}$ deform & 623.2 & $(+7.6)$ & 8.1 & $(+1.8)$ & 618.8 & $(+3.2)$ & 6.4 & $(+0.2)$ \\
\hline $\mathrm{CF}_{2}$ deform & 587.6 & $(+3.1)$ & 4.6 & $(-1.8)$ & $585 . .2$ & $(+0.7)$ & 5.3 & $(-1.1)$ \\
\hline
\end{tabular}

${ }^{\text {a }}$ Changes in values from the corresponding monomer are given in parentheses. 
Table 7

Unscaled harmonic vibrational frequencies $\left(\mathrm{cm}^{-1}\right)$ and intensities $\left(\mathrm{km} \mathrm{mol}^{-1}\right)$ of the $\mathrm{FClCO}-\mathrm{H}_{2} \mathrm{O}$ complexes calculated at the MP2/aug-cc-pVTZ level of theory ${ }^{\text {a }}$

\begin{tabular}{|c|c|c|c|c|c|c|c|c|}
\hline \multirow{2}{*}{ mode } & \multicolumn{4}{|c|}{ Complex I } & \multicolumn{4}{|c|}{ Complex II } \\
\hline & $v$ & & I & & $v$ & & I & \\
\hline $\mathrm{OH}$ a-str & 3939.4 & $(-8.9)$ & 193.4 & $(+118.4)$ & 3911.7 & $(-36.6)$ & 81.0 & $(+6.0)$ \\
\hline OH s-str & 3811.8 & $(-6.2)$ & 117.3 & $(+110.8)$ & 3784.2 & $(-33.8)$ & 10.2 & $(+3.8)$ \\
\hline $\mathrm{HOH}$ bend & 1634.9 & $(+11.7)$ & 54.6 & $(-17.4)$ & 1624.8 & $(+1.6)$ & 99.3 & $(+27.4)$ \\
\hline $\mathrm{CO}$ str & 1866.6 & $(-15.1)$ & 422.5 & $(+72.1)$ & 1881.0 & $(-0.7)$ & 338.5 & $(-11.9)$ \\
\hline CF str & 1128.3 & $(+31.2)$ & 396.5 & $(-18.7)$ & 1110.2 & $(+13.2)$ & 401.8 & $(-13.4)$ \\
\hline $\mathrm{CCl}$ str & 772.9 & $(+5.5)$ & 81.7 & $(-3.4)$ & 773.9 & $(+6.6)$ & 78.1 & $(-6.9)$ \\
\hline Op deform & 679.4 & $(+3.9)$ & 15.1 & $(+2.1)$ & 667.0 & $(-8.5)$ & 24.8 & $(+11.8)$ \\
\hline $\mathrm{CO}$ deform & 513.6 & $(+4.7)$ & 0.5 & $(+0.1)$ & 507.1 & $(-1.8)$ & 0.3 & $(0.0)$ \\
\hline $\mathrm{CFCl}$ deform & 418.7 & $(+5.5)$ & 0.3 & $(-0.2)$ & 415.3 & $(+2.1)$ & 0.6 & $(+0.1)$ \\
\hline
\end{tabular}

${ }^{a}$ Changes in values from the corresponding monomer are given in parentheses. 
Table 8

Natural atomic charges of monomers and changes in natural atomic charges of the FXCO- $\mathrm{H}_{2} \mathrm{O}$ complexes

\begin{tabular}{|c|c|c|c|}
\hline \multirow{2}{*}{ atom } & \multicolumn{2}{|c|}{$\Delta q / \mathrm{me}$} & \multirow{2}{*}{$\frac{q / \mathrm{e}}{\text { monomer }}$} \\
\hline & complex I & complex II & \\
\hline \multicolumn{4}{|l|}{$\mathrm{F}_{2} \mathrm{CO}-\mathrm{H}_{2} \mathrm{O}$} \\
\hline $\mathrm{C} 1$ & 16.67 & 30.30 & 1.31821 \\
\hline $\mathrm{O} 2$ & -31.55 & -34.78 & -0.61274 \\
\hline F3 & 11.37 & -2.10 & -0.35274 \\
\hline $\mathrm{F} 4$ & 7.13 & 2.69 & -0.35273 \\
\hline O5 & -19.42 & -10.49 & -0.93008 \\
\hline H6 & 18.94 & 8.73 & 0.46504 \\
\hline $\mathrm{H} 7$ & -3.13 & 5.65 & 0.46504 \\
\hline \multicolumn{4}{|c|}{$\mathrm{FClCO}-\mathrm{H}_{2} \mathrm{O}$} \\
\hline $\mathrm{C} 1$ & 12.09 & 25.11 & 0.97059 \\
\hline $\mathrm{O} 2$ & -33.82 & -29.81 & -0.58858 \\
\hline F3 & 9.96 & -1.47 & -0.36698 \\
\hline $\mathrm{Cl} 4$ & 15.6 & 2.3 & -0.01502 \\
\hline $\mathrm{O} 5$ & -18.85 & -14.5 & -0.93008 \\
\hline H6 & 19.06 & 11.03 & 0.46504 \\
\hline H7 & -4.05 & 7.33 & 0.46504 \\
\hline
\end{tabular}


Table 9

Charge transfer interactions in complex I

\begin{tabular}{lcc}
\hline \multicolumn{1}{c}{ Parameter $^{\mathrm{a}}$} & $\mathrm{F}_{2} \mathrm{CO}-\mathrm{H}_{2} \mathrm{O}$ & $\mathrm{FClCO}-\mathrm{H}_{2} \mathrm{O}$ \\
\hline Intermolecular & & 1.0 \\
$E^{(2)} n_{1 \mathrm{O} 2} \rightarrow \sigma^{*}{ }_{\mathrm{O} 5-\mathrm{H} 6}$ & 1.0 & 1.7 \\
$E^{(2)} n_{2 \mathrm{O} 2} \rightarrow \sigma^{*}{ }_{\mathrm{O} 5-\mathrm{H} 6}$ & 2.0 & \\
Intramolecular & -2.2 & -2.6 \\
$\Delta E^{(2)} n_{2} \mathrm{O} 2 \rightarrow \sigma^{*}{ }_{\mathrm{C} 1-\mathrm{F} 3}$ & -2.6 & -2.6 \\
$\Delta E^{(2)} n_{2 \mathrm{O} 2} \rightarrow \sigma^{*}{ }_{\mathrm{C} 1-\mathrm{X} 4}$ & +1.0 & +2.1 \\
$\Delta E^{(2)} n_{3 \mathrm{~F} 3} \rightarrow \pi^{*}{ }_{\mathrm{C} 1-\mathrm{O} 2}$ & +0.3 & +1.8 \\
$\Delta E^{(2)} n_{3 \mathrm{X} 4} \rightarrow \pi^{*}{ }_{\mathrm{C} 1-\mathrm{O} 2}$ & & \\
& +8.2 & +9.2 \\
$\Delta n_{2} \mathrm{O} 2$ & -4.2 & -4.0 \\
$\Delta n_{3 \mathrm{~F} 3}$ & -3.0 & -4.8 \\
$\Delta n_{3 \mathrm{X} 4}$ & +3.2 & +1.2 \\
$\Delta \sigma_{\mathrm{C} 1-\mathrm{O} 2}$ & +5.3 & +8.5 \\
$\Delta \pi_{\mathrm{C} 1-\mathrm{O} 2}^{\Delta \sigma_{\mathrm{C} 1-\mathrm{F} 3}}$ & -5.0 & -5.0 \\
$\Delta \sigma_{\mathrm{C} 1-\mathrm{X} 4}$ & -4.3 & -5.5 \\
$\Delta \sigma_{\mathrm{O} 5-\mathrm{H} 6}$ & +3.5 & +3.5 \\
\hline
\end{tabular}

${ }^{\mathrm{a}}$ The second-order perturbation energies are given in $\mathrm{kcal} \mathrm{mol}^{-1}$. The changes in the orbital population are given in me. 
Table 10

Charge transfer interactions in complex II

\begin{tabular}{lcc}
\hline \multicolumn{1}{c}{ Parameter $^{\mathrm{a}}$} & $\mathrm{F}_{2} \mathrm{CO}-\mathrm{H}_{2} \mathrm{O}$ & $\mathrm{FClCO}-\mathrm{H}_{2} \mathrm{O}$ \\
\hline Intermolecular & & \\
$E^{(2)} n_{2 \mathrm{O} 5} \rightarrow \pi^{*}{ }_{\mathrm{C} 1-\mathrm{O} 2}$ & 2.55 & 1.97 \\
$E^{(2)} \pi_{\mathrm{C} 1-\mathrm{O} 2} \rightarrow \sigma^{*}{ }_{\mathrm{O} 5-\mathrm{H} 7}$ & 0.24 & 0.25 \\
Intramolecular & & \\
$\Delta E^{(2)} n_{2 \mathrm{O} 2} \rightarrow \sigma^{*}{ }_{\mathrm{C} 1-\mathrm{F} 3}$ & +1.68 & -0.64 \\
$\Delta E^{(2)} n_{2} \mathrm{O} 2 \rightarrow \sigma^{*}{ }_{\mathrm{C} 1-\mathrm{X} 4}$ & +1.13 & -0.25 \\
$\Delta E^{(2)} n_{3 \mathrm{~F} 3} \rightarrow \pi^{*}{ }_{\mathrm{C} 1-\mathrm{O} 2}$ & +1.44 & +0.88 \\
$\Delta E^{(2)} n_{3 \mathrm{X} 4} \rightarrow \pi^{*}{ }_{\mathrm{C} 1-\mathrm{O} 2}$ & +2.22 & +0.53 \\
& & \\
$\Delta n_{2} \mathrm{O} 2$ & +2.5 & +2.3 \\
$\Delta \sigma_{\mathrm{C} 1-\mathrm{O} 2}$ & +1.2 & +1.0 \\
$\Delta \pi^{*}{ }_{\mathrm{C} 1-\mathrm{O} 2}$ & +5.7 & +5.1 \\
$\Delta \sigma_{\mathrm{C} 1-\mathrm{F} 3}$ & +1.2 & -0.52 \\
$\Delta \sigma_{\mathrm{C} 1-\mathrm{X} 4}^{\Delta n_{2} \mathrm{O} 5}$ & -0.3 & -0.48 \\
\hline
\end{tabular}

${ }^{\mathrm{a}}$ The second-order perturbation energies are given in $\mathrm{kcal} \mathrm{mol}^{-1}$. The changes in the orbital population are given in me. 
(a)

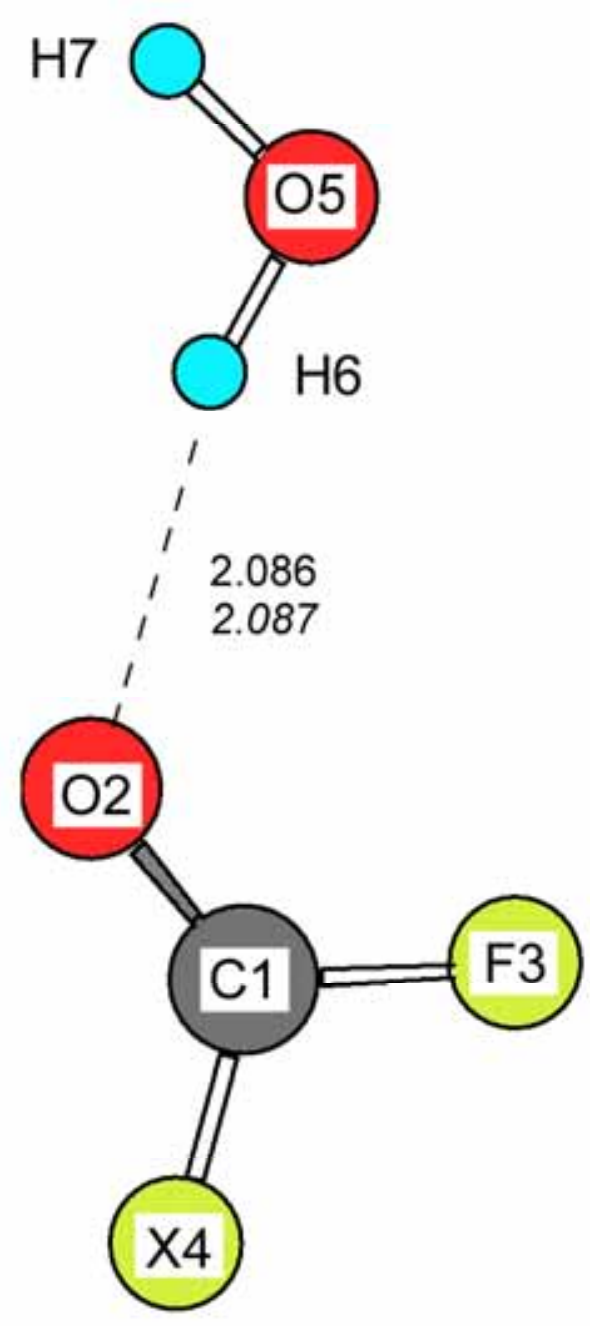

(b)

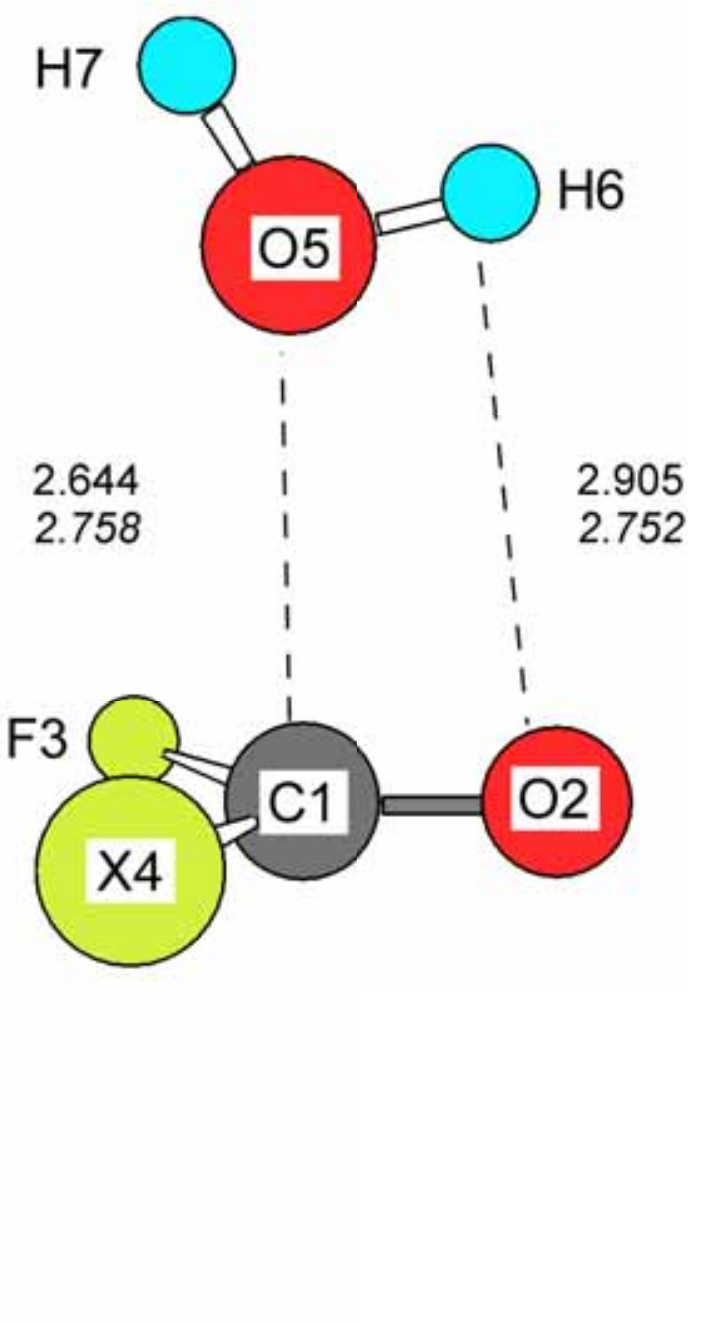

Fig. 1. Tanaka et al. "Theoretical studies on carbonyl halide-water complexes" 


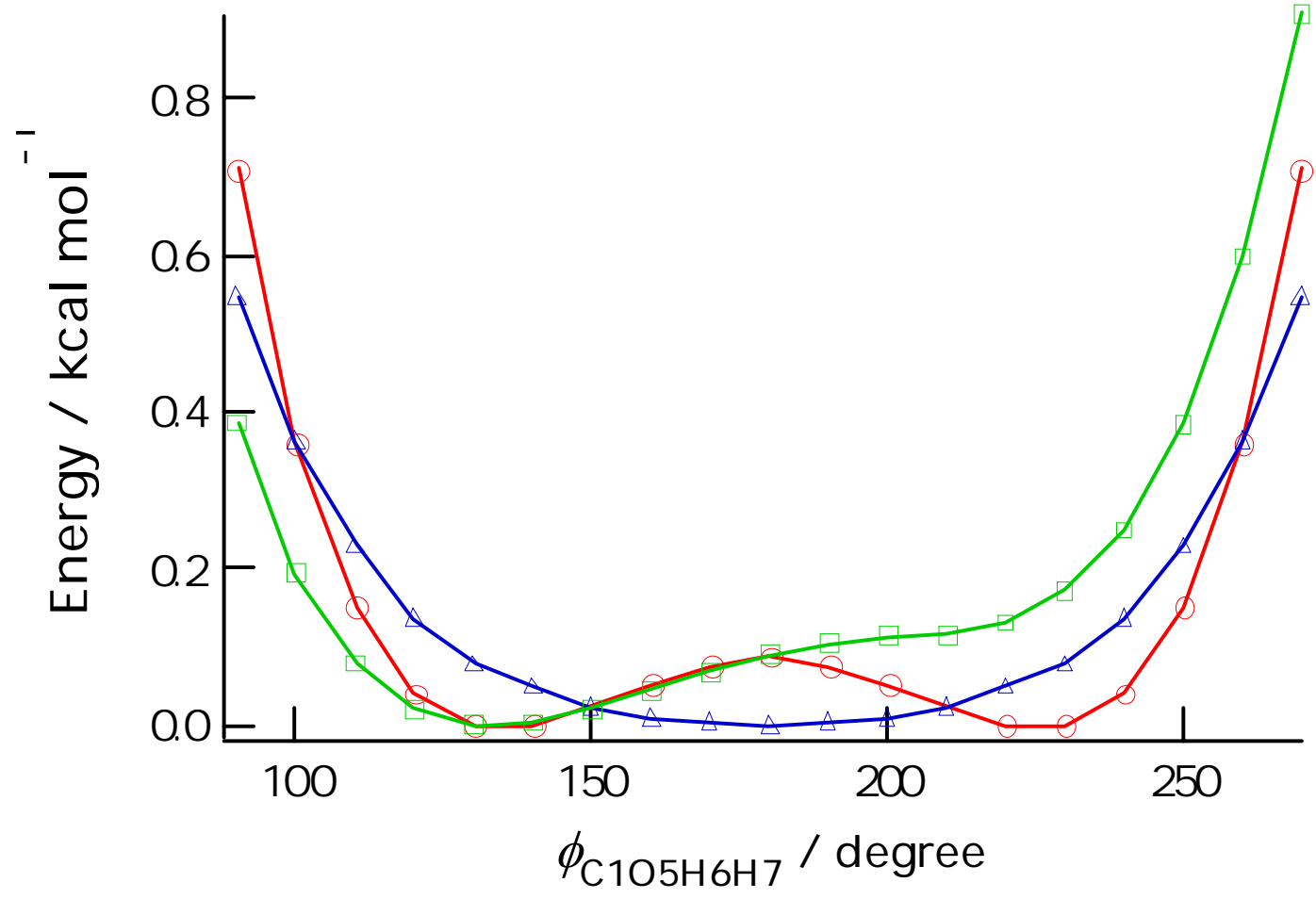

Fig. 2. Tanaka et al. "Theoretical studies on carbonyl halide-water complexes" 


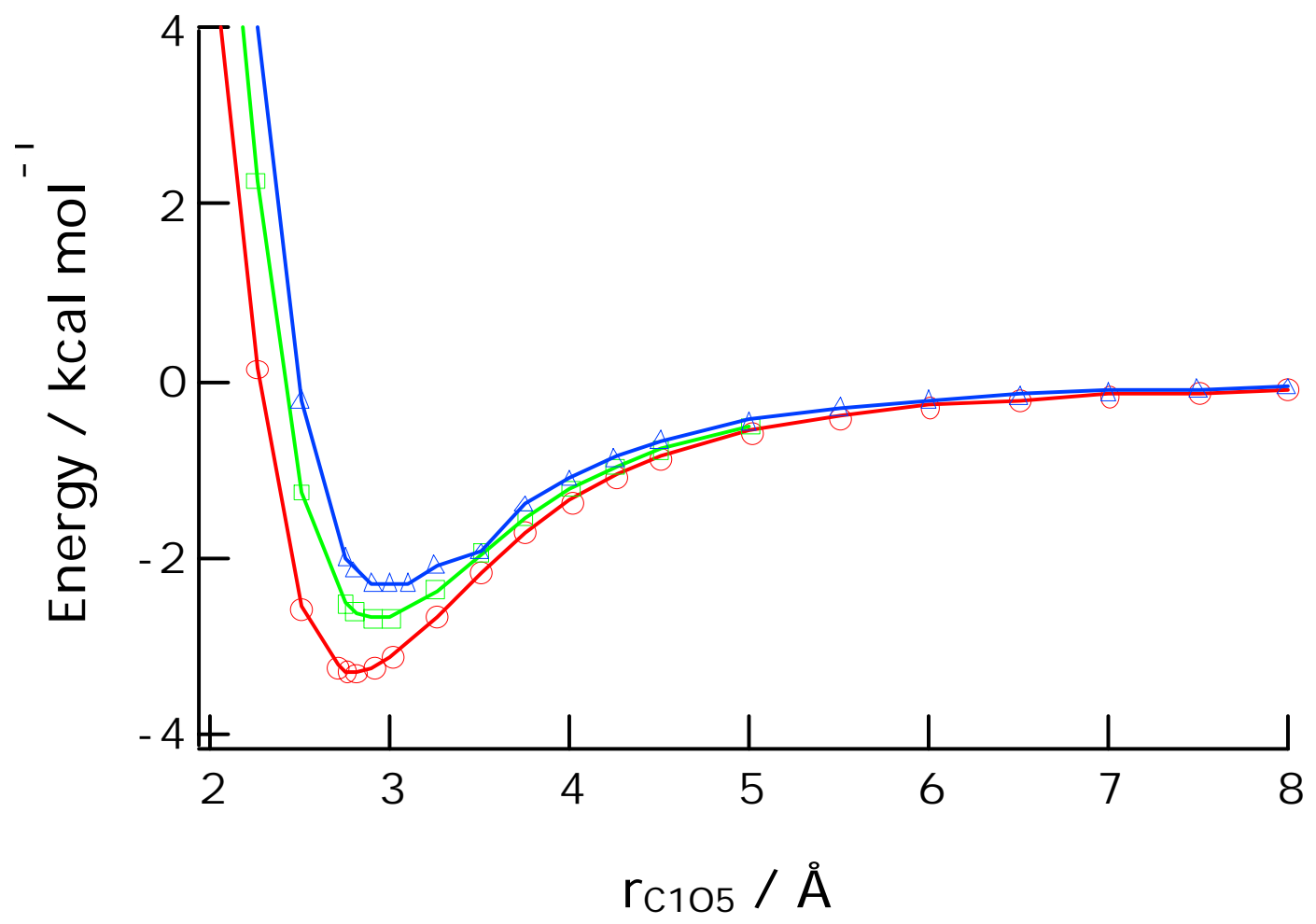

Fig. 3. Tanaka et al. "Theoretical studies on carbonyl halide-water complexes" 
(a)
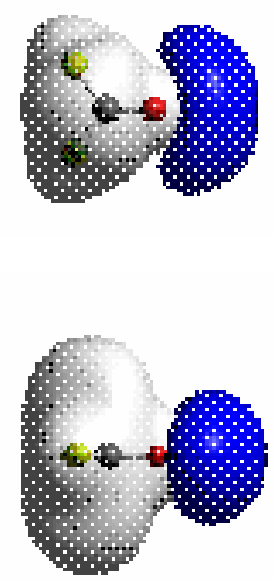

(b)
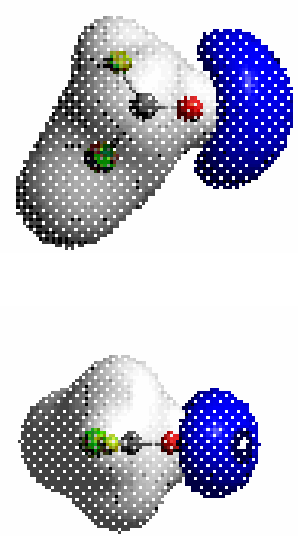

(c)
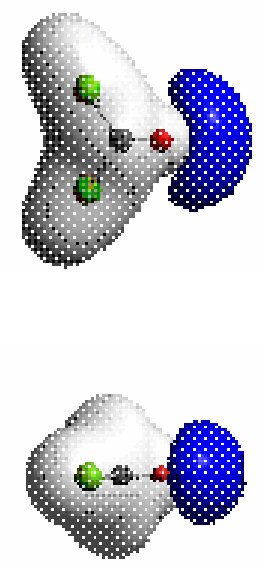

Fig. 4. Tanaka et al. "Theoretical studies on carbonyl halide-water complexes" 